\title{
Simultaneous Determination of Rosuvastatin and Ezetimibe in pharmaceutical formulations by Stability Indicating Liquid Chromatographic Method
}

\author{
Mathrusri Annapurna Mukthinuthalapati*, Venkatesh Bukkapatnam¹, Sai Pavan Kumar Bandaru and Naga Supriya Grandhi \\ ${ }^{1}$ Department of Pharmaceutical Analysis and Quality Assurance, GITAM Institute of Pharmacy, GITAM University, Visakhapatnam, India \\ ${ }^{2}$ Roland Institute of Pharmaceutical Sciences, Berhampur, Orissa
}

\begin{abstract}
Rosuvastatin and Ezetimibe are used for the treatment of hyperlipidemia. A stability-indicating RP-HPLC method was developed and validated for the simultaneous determination of Rosuvastatin and Ezetimibe in tablet dosage forms using C 18 column with mobile phase consisting of tetra butyl ammonium hydrogen sulphate-acetonitrile $(32: 68, \mathrm{v} / \mathrm{v})$ with a flow rate of $1.0 \mathrm{ml} / \mathrm{min}$ (UV detection $254 \mathrm{~nm}$ ). Linearity was observed over the concentration range $0.1-200 \mu \mathrm{g} / \mathrm{ml}$ for both Rosuvastatin $\left(r^{2}=0.9998\right)$ and Ezetimibe $\left(r^{2}=0.9998\right)$. The LOD and LOQ were found to be $0.0282 \mu \mathrm{g} / \mathrm{ml}$ and $0.0853 \mu \mathrm{g} / \mathrm{m}$ for Rosuvastatin and the LOD and LOQ for Ezetimibe were $0.0297 \mu \mathrm{g} / \mathrm{ml}$ and $0.0901 \mu \mathrm{g} / \mathrm{ml}$ respectively. Rosuvastatin and Ezetimibe were subjected to stress conditions of degradation in aqueous solutions including acidic, alkaline, oxidation, photolysis and thermal degradation. Ezetimibe is highly sensitive towards alkaline conditions. The method was validated as per ICH guidelines. The percentage RSD for intra-day precision was found to be 0.41-0.94 and 0.31-0.59 for Rosuvastatin and Ezetimibe respectively whereas the inter-day precision was found to be $0.68-0.95$ and $0.68-1.02$ for Rosuvastatin and Ezetimibe respectively. The method is simple, specific, precise, robust and accurate for the simultaneous determination of Rosuvastatin and Ezetimibe in pharmaceutical dosage forms (Tablets).
\end{abstract}

Keywords: Rosuvastatin; Ezetimibe; RP-HPLC; Stability-indicating; $\mathrm{ICH}$

\section{Introduction}

Ezetimibe (EZT) chemically [1] designated as (3R, 4S) - 1 - (4 fluorophenyl) - 3 - [(3S) - 3 - (4 - fluorophenyl) - 3 - hydroxypropyl] - 4 - (4 - hydroxyphenyl) azetidin - 2 - one (Figure 1A). It is a selective cholesterol absorption inhibitor, used for the treatment of hyperlipidemia, which potentially inhibits the absorption of biliary and dietary cholesterol. Ezetimibe prevents intestinal absorption of cholesterol without affecting absorption of triglycerides, fatty acids, bile acids and fat-soluble vitamins [2-4].

Rosuvastatin (RST) (Figure 1B) is a selective and competitive inhibitor of hydroxylmethylglutaryl coenzymeA(HMGCoA) reductase, the rate- limiting enzyme that converts 3-hydroxyl-3-methylglutaryl coenzyme A to mevalonate, a precursor of cholesterol. Rosuvastatin is a member of the class 'statins' and chemically designated as $(3 \mathrm{R}, 5 \mathrm{~S}$, 6E) - 7 - [4 - (4 - fluorophenyl) - 2 - (N - methylmethanesulfonamido) - 6 - (propan - 2 - yl) pyrimidin - 5 - yl] - 3, 5 - dihydroxyhept - 6 enoic acid [1]. It is used for the treatment of Hyperlipidemia. It reduces levels of low-density lipoprotein, apolipoprotein B and triglycerides in the blood, while increasing levels of high-density lipoprotein in the management of hyper lipidaemias [5]. Various analytical techniques such as micellar liquid chromatography [6], HPLC [7-13], HPTLC [14,15], densitometric TLC [16], spectrophotometry [17-19] and spectrofluorimetry [20] have been developed for the simultaneous determination of Rosuvastatin and Ezetimibe in pharmaceutical formulations. In the present study the authors have developed a validated stability indicating liquid chromatographic method for the simultaneous determination of Rosuvastatin and Ezetimibe in pharmaceutical formulations [21]. As no suitable stability indicating method was reported before, a simple, rapid, precise, accurate and robust stability indicating liquid chromatographic method has been developed for the simultaneous determination of Rosuvastatin and Ezetimibe in tablets and validated as per ICH guidelines [22]

\section{Experimental}

\section{Reagents and solutions}

Reference standards of Rosuvastatin (purity 99\%) and Ezetimibe (purity 99.5\%) were obtained from Glenmark Pharmaceuticals Ltd., India. The combination of Rosuvastatin and Ezetimibe is available as film-coated tablets (10 mg of Rosuvastatin and $10 \mathrm{mg}$ of Ezetimibe) with brand names RAZEL-EZ (Glenmark Pharmaceuticals Ltd., India) and ROSUVAS-EZ (Ranbaxy Laboratories Ltd., India) and were procured from the local pharmacy store. Acetonitrile (HPLC grade), tetra butyl ammonium hydrogen sulphate (TBAHS) sodium hydroxide and hydrochloric acid and hydrogen peroxide were purchased from Merck (India).

Tetra butyl ammonium hydrogen sulphate buffer (pH 3.4) solution

The mobile phase was prepared by accurately transferring $3.3954 \mathrm{~g}$ of TBAHS in to a $1000 \mathrm{~mL}$ volumetric flask and dissolved with HPLC grade water.

*Corresponding author: Mathrusri Annapurna M, Department of Pharmaceutical Analysis and Quality Assurance, GITAM Institute of Pharmacy, GITAM University, Visakhapatnam, India, Tel: 918912790101; E-mail: mathrusri2000@yahoo.com

Received September 24, 2014; Accepted October 24, 2014; Published October 31,2014

Citation: Mukthinuthalapati MA, Bukkapatnam V, Bandaru SPK, Grandhi NS (2014) Simultaneous Determination of Rosuvastatin and Ezetimibe in pharmaceutical formulations by Stability Indicating Liquid Chromatographic Method. J Bioequiv Availab 6: 174-180. doi:10.4172/jbb. 1000200

Copyright: (c) 2014 Mukthinuthalapati MA, et al. This is an open-access article distributed under the terms of the Creative Commons Attribution License, which permits unrestricted use, distribution, and reproduction in any medium, provided the original author and source are credited. 
$[\mathbf{A}]$<smiles>CC(C)c1nc(N(C)S(C)(=O)=O)nc(-c2ccc(F)cc2)c1/C=C/[C@H](O)C[C@@H](O)CC(=O)O</smiles>

$[B]$

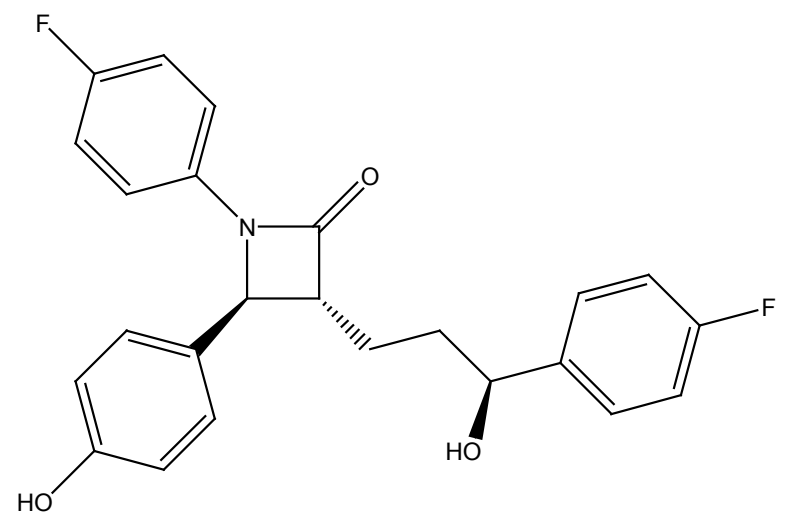

Figure 1: Chemical structures of Rosuvastatin $[A]$ and Ezetimibe $[B]$.

\section{Preparation of rosuvastatin and ezetimibe stock solutions (1 $\mathbf{m g} / \mathbf{m l})$}

Stock solutions of Rosuvastatin $(1000 \mu \mathrm{g} / \mathrm{ml})$ and Ezetimibe $(1000 \mu \mathrm{g} / \mathrm{ml})$ were prepared by accurately transferring $25 \mathrm{mg}$ of Rosuvastatin and Ezetimibe separately in two $25 \mathrm{ml}$ volumetric flasks and the volume was made up to volume with mobile phase. Working solutions for HPLC injections were prepared on a daily basis from the stock solution with mobile phase containing tetra butyl ammonium hydrogen sulphate and acetonitrile $(32: 68, \mathrm{v} / \mathrm{v})$. Solutions were filtered through a $0.45 \mu \mathrm{m}$ membrane filter prior to injection.

\section{HPLC instrumentation and conditions}

ChromatographicseparationwasachievedbyusingaShimadzuModel CBM-20A/20 Alite HPLC system, equipped with SPD M20A prominence photodiode array detector $(250 \mathrm{~mm} \times 4.6 \mathrm{~mm}, 5 \mu \mathrm{m}$ particle size) maintained at $25^{\circ} \mathrm{C}$. Isocratic elution was performed using tetra butyl ammonium hydrogen sulphate-acetonitrile (32:68, $\mathrm{v} / \mathrm{v}$ ) with a flow rate of $1.0 \mathrm{ml} / \mathrm{min}$ (UV detection $254 \mathrm{~nm}$ ). $20 \mu \mathrm{l}$ of sample was injected into the HPLC system and all chromatographic conditions were performed at room temperature $\left(25^{\circ} \mathrm{C} \pm 2^{\circ} \mathrm{C}\right)$.

\section{Method validation}

The method was validated for the following parameters: linearity, precision, accuracy, selectivity, robustness, limit of quantitation (LOQ), limit of detection (LOD) and system suitability [21].

\section{Linearity}

Linearity test solutions for the assay method were prepared from a stock solution at different concentration levels and $20 \mu \mathrm{L}$ of each solution was injected in to the HPLC system and the peak area of the chromatogram obtained was noted.

The solutions extracted from the marketed formulations were also injected into the HPLC system and the peak area of the chromatograms was noted. A calibration curve was plotted by taking concentration of the drug solution on the $\mathrm{x}$-axis and the corresponding peak area on the y-axis.

\section{Precision}

The intra-day precision of the assay method was evaluated at three concentration levels $(10,50$ and $100 \mu \mathrm{g} / \mathrm{ml})(\mathrm{n}=3)$ against a qualified reference standard. The inter-day precision study was performed on three different days i.e. day 1 , day 2 and day 3 at three different concentration levels $(10,50$ and $100 \mu \mathrm{g} / \mathrm{ml})(\mathrm{n}=3)$. The \%RSD of the obtained assay values at three different concentration levels was calculated.

\section{Accuracy}

The method accuracy was proved by the recovery test. The accuracy of the assay method was evaluated in triplicate at three concentration levels (80, 100 and 120\%), and the percentage recoveries were calculated. A known amount of Rosuvastatin and Ezetimibe standards $(10 \mu \mathrm{g} / \mathrm{ml})$ were added to aliquots of sample solutions and then diluted to yield the total concentrations of 18,20 and $22 \mu \mathrm{g} / \mathrm{ml}$.

\section{LOQ and LOD}

The LOQ and LOD were based on the standard deviation of the response and the slope of the constructed calibration curve $(n=3)$, as described in International Conference on Harmonization guidelines Q2 (R1) [21].

\section{Robustness}

The robustness of the assay method was established by introducing small changes in the HPLC conditions which included wavelength (252 and $256 \mathrm{~nm}$ ), percentage of acetonitirile in the mobile phase (34 and 30) and flow rate $(0.9$ and $1.1 \mathrm{ml} / \mathrm{min})$. Robustness of the method was studied using six replicates at a concentration level of $100 \mu \mathrm{g} / \mathrm{ml}$ of Rosuvastatin and Ezetimibe.

\section{Forced degradation studies/Specificity}

Stress studies were performed to evaluate the specificity of the method [22]. All samples were diluted with mobile phase to give a final concentration $100 \mu \mathrm{g} / \mathrm{ml}$ and filtered through $0.45 \mu \mathrm{m}$ nylon filter before injection.

Acidic conditions: Acidic degradation was performed by treating the drug solution mixture (containing each of $1 \mathrm{mg} / \mathrm{ml}$ Rosuvastatin and Ezetimibe) with $0.1 \mathrm{~N}$ hydrochloric acid for $30 \mathrm{~min}$ in a thermostat maintained at $60^{\circ} \mathrm{C}$. The drug solution mixture was cooled, neutralized with $0.1 \mathrm{~N}$ sodium hydroxide and then diluted with mobile phase as per the requirement and $20 \mu \mathrm{L}$ of the solution was injected in to the HPLC system.

Alkaline conditions: Alkaline degradation was performed by treating the drug solution mixture (containing each of $1 \mathrm{mg} /$ $\mathrm{ml}$ Rosuvastatin and Ezetimibe) with $0.1 \mathrm{~N}$ sodium hydroxide for $30 \mathrm{~min}$ in a thermostat maintained at $60^{\circ} \mathrm{C}$. The drug solution mixture was cooled, neutralized with $0.1 \mathrm{~N}$ hydrochloric acid and then diluted with mobile phase as per the requirement and $20 \mu \mathrm{L}$ of the solution was injected in to the HPLC system. 
Oxidation conditions: Oxidation degradation was performed by treating the drug solution mixture (containing each of $1 \mathrm{mg} / \mathrm{ml}$ Rosuvastatin and Ezetimibe) with $30 \% \mathrm{H}_{2} \mathrm{O}_{2}$ for 30 min in a thermostat maintained at $60^{\circ} \mathrm{C}$. The drug solution mixture was cooled and then diluted with mobile phase as per the requirement and $20 \mu \mathrm{L}$ of the solution was injected in to the HPLC system.

Photolytic conditions: The drug solution mixture (containing each of $1 \mathrm{mg} / \mathrm{ml}$ Rosuvastatin and Ezetimibe) was exposed to UV light $(365 \mathrm{~nm})$ for 3 hours, diluted with mobile phase as per the requirement and $20 \mu \mathrm{L}$ of the solution was injected in to the HPLC system.

Thermal conditions: The drug solution mixture (containing each of $1 \mathrm{mg} / \mathrm{ml}$ Rosuvastatin and Ezetimibe) was in a thermostat maintained at $60^{\circ} \mathrm{C}$ for 8 hours, cooled and $20 \mu \mathrm{L}$ of the solution was injected in to the HPLC system after necessary dilution with mobile phase.

\section{Solution stability and mobile phase stability}

The solution stability of Rosuvastatin and Ezetimibe in the assay method was carried out by leaving both the sample and reference standard solutions in tightly capped volumetric flasks at room temperature for $48 \mathrm{~h}$. The same sample solutions were assayed at 12 $\mathrm{h}$ intervals over the study period. The mobile phase stability was also assessed by assaying the freshly prepared sample solutions against freshly prepared reference standard solutions at $12 \mathrm{~h}$ intervals up to $48 \mathrm{~h}$. The prepared mobile phase remained constant during the study period. The \% RSD of the Rosuvastatin and Ezetimibe assay was calculated for the mobile phase and solution stability experiments. An additional study was carried out using the stock solution by storing it in a tightly capped volumetric flask at $4^{\circ} \mathrm{C}$.

\section{Analysis of tablet formulation}

Twenty tablets from each brand (RAZEL-EZ and ROSUVASEZ ${ }^{\circ}$ ) were procured, weighed and crushed to a fine powder. Powder equivalent to $25 \mathrm{mg} 25 \mathrm{mg}$ of Rosuvastatin and Ezetimibe was accurately weighed into a $25 \mathrm{~mL}$ volumetric flask and made up to volume with mobile phase. The contents of the volumetric flask were sonicated for $30 \mathrm{~min}$ to enable complete dissolution of both the drugs. The solution was filtered and diluted with mobile phase as per the requirement. $20 \mu \mathrm{L}$ of these solutions were injected into the system after filtering through $0.45 \mu \mathrm{m}$ membrane and the peak area was recorded from the respective chromatogram.

\section{Results and Discussion}

\section{HPLC method development and optimization}

Initially the stressed samples were analyzed using a mobile phase consisting of TBAHS: acetonitrile (30:70, v/v) at a flow rate of 1.2 $\mathrm{ml} / \mathrm{min}$. Under these conditions, the resolution was not satisfactory. Therefore the mobile phase composition was changed to $32: 68$, v/v with a flow rate $1.0 \mathrm{ml} / \mathrm{min}$ under which the resolution was good. Therefore mobile phase consisting of TBAHS: acetonitrile $(32: 68, \mathrm{v} / \mathrm{v})$ with a flow rate of $1.0 \mathrm{ml} / \mathrm{min}$ was chosen as the best chromatographic response for the simultaneous determination of Rosuvastatin and Ezetimibe. UV detection was carried out at $254 \mathrm{~nm}$ (PDA detector). The present proposed method was compared with the previously published HPLC methods in the literature and discussed in Table 1.

\section{Method validation}

Linearity: The combination of Rosuvastatin and Ezetimibe shows linearity over a concentration range of $0.1-200 \mu \mathrm{g} / \mathrm{ml}$ (Table 2) and the linear regression equations were found to be $\mathrm{y}=34716 \mathrm{x}+3830.3\left(\mathrm{r}^{2}=0.9998\right)$ and $\mathrm{y}=44508 \mathrm{x}+25845\left(\mathrm{r}^{2}=0.9998\right)$ for Rosuvastatin and Ezetimibe respectively. The chromatograms of the mobile phase (blank) and that of the combination of Rosuvastatin and Ezetimibe were shown in Figure 2A-B respectively.

Accuracy: The accuracy study was repeated over three consecutive days and the resultant \% RSD was found to be $0.10-0.14$ and $0.10-0.63$ for Rosuvastatin and Ezetimibe indicating that the method is precise. The recovery of for Rosuvastatin and Ezetimibe was found to be 99.38 $99.95 \%$ and $98.97-99.80 \%$ respectively (Table 3 ).

Precision: The \% RSD for intra-day precision was found to be 0.41 0.94 and 0.31-0.59 for Rosuvastatin and Ezetimibe respectively whereas the inter-day precision was found to be $0.68-0.95$ and $0.68-1.02$ for Rosuvastatin and Ezetimibe respectively (Table 4).

\section{Sensitivity/ Limit of quantification (LOQ) and limit of detection (LOD)}

The LOD and LOQ were found to be $0.0282 \mu \mathrm{g} / \mathrm{ml}$ and $0.0853 \mu \mathrm{g} /$ $\mathrm{ml}$ for Rosuvastatin and the LOD and LOQ for Ezetimibe were 0.0297 $\mu \mathrm{g} / \mathrm{ml}$ and $0.0901 \mu \mathrm{g} / \mathrm{ml}$ respectively.

Robustness: Usually a slight change in flow rate, mobile phase composition etc. affects the chromatographic response such as retention time, tailing factor and theoretical plates etc. During this study the theoretical plates were found to be more than 2000 for both the drugs and at the same time the \% RSD was found to be $<2.0 \%(0.52-0.95 \%$ and 0.71-1.38 \% for Rosuvastatin and Ezetimibe respectively) indicating that the proposed method is robust. The results were shown in Table 5.

Solution stability and mobile phase stability: The \% RSD for the solution stability was found to be 0.0149 and 0.0153 and for mobile

\begin{tabular}{|c|c|c|c|c|}
\hline Method/Reagent & $\lambda(\mathrm{nm})$ & Linearity $(\mu \mathrm{g} / \mathrm{ml})$ & Remarks & Ref. \\
\hline $\begin{array}{l}\text { Methanol: acetonitrile: phosphate buffer } \\
(60: 20: 20, v / v)(\mathrm{pH} 3.5)\end{array}$ & 279 & $5-10 \times 10^{3}$ & Micellar liquid chromtography & [7] \\
\hline $\begin{array}{l}\text { Acetonitrile: methanol: } \mathrm{K}_{2} \mathrm{HPO}_{4}(\mathrm{pH} 3.0) \\
(34.27: 20: 45.73, \mathrm{v} / \mathrm{v} / \mathrm{v})\end{array}$ & 239 & $0.5-1.0$ & Not stability indicating & [8] \\
\hline Ammonium buffer: acetonitrile $(55: 45, \mathrm{v} / \mathrm{v})(\mathrm{pH} 6.5)$ & 230 & $\begin{array}{l}98.19-294.56 \text { (RSV) } \\
99.12-297.36 \text { (EZT) }\end{array}$ & Low linearity range & [9] \\
\hline Phosphate buffer: methanol $(45: 55, \mathrm{v} / \mathrm{v})(\mathrm{pH} 2.5)$ & 242 & $5-80$ & Low linearity range & [10] \\
\hline $\begin{array}{l}\text { Ortho phosphoric acid : acetonitrile } \\
(63: 37, \mathrm{v} / \mathrm{v})(\mathrm{pH} 3.5)\end{array}$ & 245 & $0.5-10$ & Not stability indicating & [11] \\
\hline $\begin{array}{l}\text { Ammonium acetate buffer: methanol: acetonitrile } \\
(30: 40: 30, v / v / v)(p H 7.2)\end{array}$ & 239 & $0.5-5 \times 10^{3}$ & Not stability indicating & [12] \\
\hline Acetonitrile: methanol: sod. di hydrogen phosphate $(30: 20: 50, \mathrm{v} / \mathrm{v})$ & 263 & $10-60$ & Not stability indicating & [13] \\
\hline $\begin{array}{l}\text { Tetra butyl ammonium hydrogen sulphate: acetonitrile } \\
(32: 68, \mathrm{v} / \mathrm{v})(\mathrm{pH} 3.4)\end{array}$ & 254 & $0.5-200$ & $\begin{array}{l}\text { Stability indicating \& wide linearity } \\
\text { range }\end{array}$ & Present work \\
\hline
\end{tabular}

Table 1: Comparison of Performance Characteristics of the Present Method with the Previously Published HPLC Methods. 


\begin{tabular}{|c|c|c|}
\hline Conc. $(\mu \mathrm{g} / \mathrm{ml})$ & ${ }^{*}$ Mean peak area \pm SD & *\%RSD \\
\hline \multicolumn{3}{|c|}{ Rosuvastatin } \\
\hline 0.1 & $3387 \pm 7.11$ & 0.21 \\
\hline 1 & $34320 \pm 126.98$ & 0.37 \\
\hline 5 & $163427 \pm 179.77$ & 0.11 \\
\hline 10 & $348814 \pm 976.68$ & 0.28 \\
\hline 20 & $702587 \pm 632.33$ & 0.09 \\
\hline 50 & $1729365 \pm 3112.86$ & 0.18 \\
\hline 100 & $3562713 \pm 7837.97$ & 0.22 \\
\hline 150 & $5146587 \pm 18013.05$ & 0.35 \\
\hline 200 & $6954369 \pm 39639.90$ & 0.57 \\
\hline \multicolumn{3}{|c|}{ Ezetimibe } \\
\hline 0.1 & $4137 \pm 22.34$ & 0.54 \\
\hline 1 & $40994 \pm 147.58$ & 0.36 \\
\hline 5 & $216687 \pm 238.36$ & 0.11 \\
\hline 10 & $412443 \pm 1484.79$ & 0.36 \\
\hline 20 & $803747 \pm 3456.11$ & 0.43 \\
\hline 50 & $2247531 \pm 4719.82$ & 0.21 \\
\hline 100 & $4355771 \pm 3920.19$ & 0.09 \\
\hline 150 & $6619726 \pm 29126.79$ & 0.44 \\
\hline 200 & $8927091 \pm 45528.16$ & 0.51 \\
\hline
\end{tabular}

Table 2: Linearity of Rosuvastatin and Ezetimibe.

phase stability was 0.0875 and $0.0843(<2 \%)$ for Rosuvastatin and Ezetimibe respectively indicating that the mobile phase as well as the sample solutions used during the assays were stable up to $48 \mathrm{~h}$ at room temperature (Table 6).

Analysis of commercial formulations: The proposed method was applied for the determination of Rosuvastatin and Ezetimibe in marketed formulations available (RAZEL-EZ ${ }^{\circ}$ and ROSUVAS-EZ). The \% recovery was found to be 98.57-98.71 and 96.02-96.19 for
Rosuvastatin and Ezetimibe respectively (Table 7). The resultant chromatograms obtained from the extraction of marketed formulations were shown in Figure 2C-D.

Forced degradation studies: Rosuvastatin is highly resistant towards acidic, alkaline, oxidation, thermal and photolytic degradations as the percentage of degradation was found to be less than $10 \%$. Ezetimibe has extensively undergone alkaline degradation (94.73\%) and the phenolic hydroxyl group present in the chemical structure may be responsible for this. The resolution was found to be 6.272 and 5.123 (degradation product, $\mathrm{R}_{\mathrm{t}} 5.950 \mathrm{~min}$ ) which is greater than 2. During the oxidation an extra peak was observed at $2.502 \mathrm{~min}$. and the resolution was found to be 7.261. The resultant chromatograms obtained during the forced degradation studies were shown in Figure 3A-E. The system suitability parameters for all the degradation studies were shown in Table 8 .

\section{Discussion}

The present proposed method can be successfully applicable to perform long-term and accelerate stability studies of Rosuvastatin and Ezetimibe formulations. The complete separation of the analytes was accomplished in less than $10 \mathrm{~min}$. In literature no suitable robust and validated stability indicating methods are available with wide linearity range and instead a mixture of solvents were employed as mobile phase.

The system suitability parameters such as the number of theoretical plates $(\mathrm{N})$ is used to determine the performance and effectiveness of the column. The efficiency of a column can be measured by the number of theoretical plates per meter. It is a measure of band spreading of a peak. Smaller the band spread, higher is the number of theoretical plates, indicating good column and system performance. Columns with $\mathrm{N}$ ranging from 5,000 to 100,000 plates / meter are ideal for a good system. In the present method during all the stress studies, the

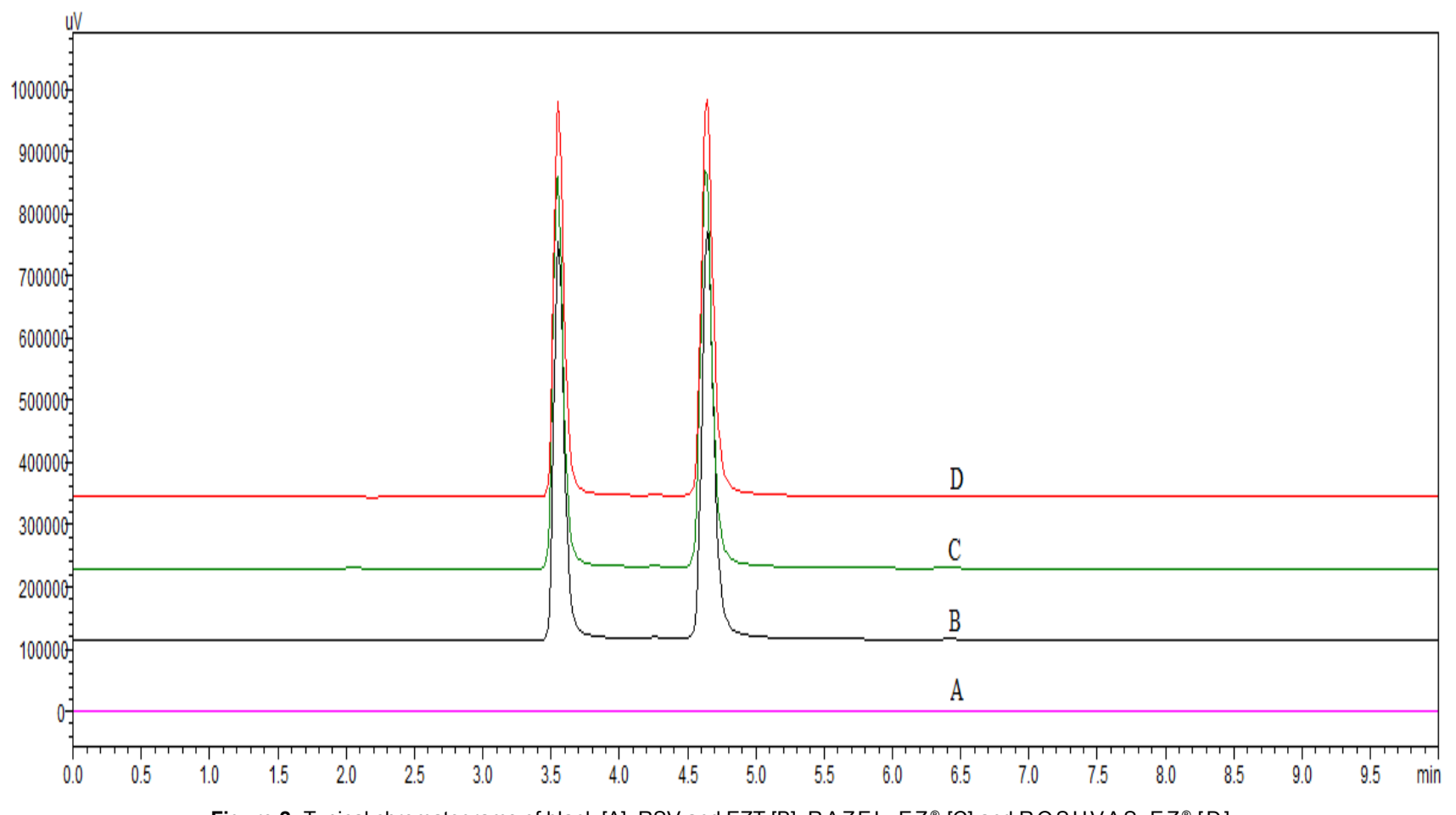

Figure 2: Typical chromatograms of blank $[A], R S V$ and $E Z T[B], R A Z E L-E Z{ }^{\circledR}[C]$ and ROSUVAS-EZ ${ }^{\circledR}[D]$. 
Citation: Mukthinuthalapati MA, Bukkapatnam V, Bandaru SPK, Grandhi NS (2014) Simultaneous Determination of Rosuvastatin and Ezetimibe in pharmaceutical formulations by Stability Indicating Liquid Chromatographic Method. J Bioequiv Availab 6: 174-180. doi:10.4172/jbb.1000200

\begin{tabular}{|c|c|c|c|c|c|c|}
\hline \multirow{2}{*}{ Drugs } & \multicolumn{3}{|c|}{ Conc. $(\mu \mathrm{g} / \mathrm{ml})$} & \multirow{2}{*}{${ }^{*}$ Mean peak area \pm SD (\% RSD) } & \multirow{2}{*}{ Drug found ( $\mu \mathrm{g} / \mathrm{ml})$} & \multirow{2}{*}{$\%$ Recovery } \\
\hline & Formulation & Pure drug & Total & & & \\
\hline \multirow{3}{*}{ Rosuvastatin } & 10 & 8 & 11 & $628394.67 \pm 653.53(0.10)$ & 17.99 & 99.95 \\
\hline & 10 & 10 & 20 & $696770.33 \pm 952.04(0.14)$ & 19.96 & 99.80 \\
\hline & 10 & 12 & 22 & $762850.00 \pm 881.30(0.12)$ & 21.86 & 99.38 \\
\hline \multirow{3}{*}{ Ezetimibe } & 10 & 8 & 18 & $820472.67 \pm 3162.31(0.39)$ & 17.85 & 99.19 \\
\hline & 10 & 10 & 20 & $914191.67 \pm 947.12(0.10)$ & 19.96 & 99.80 \\
\hline & 10 & 12 & 22 & $994905.00 \pm 6310.08(0.63)$ & 21.77 & 98.97 \\
\hline
\end{tabular}

Table 3: Accuracy Studies of Rosuvastatin and Ezetimibe.

\begin{tabular}{|c|c|c|c|}
\hline \multirow{2}{*}{ Drugs } & Conc. $(\boldsymbol{\mu g} / \mathbf{m l})$ & Intra-day precision & Inter-day precision \\
\cline { 2 - 4 } & 10 & Mean peak area \pm SD (\% RSD) & \multicolumn{1}{|c|}{$346293.00 \pm 2281.26(0.66)$} \\
\hline \multirow{3}{*}{ Rosuvastatin } & 50 & $348863.33 \pm 1047.48(0.30)$ & $1716940.00 \pm 10770.65(0.63)$ \\
\cline { 2 - 4 } & 100 & $1733410.33 \pm 3549.39(0.20)$ & $3544987.67 \pm 15370.90(0.43)$ \\
\hline \multirow{2}{*}{ Ezetimibe } & 10 & $4600587.67 \pm 21498.47(0.60)$ & $408913.00 \pm 3086.61(0.75)$ \\
\cline { 2 - 4 } & 100 & $2242036.00 \pm 6922.85(0.31)$ & $2224092.00 \pm 21013.66(0.95)$ \\
\hline
\end{tabular}

Table 4: Precision Studies of Rosuvastatin and Ezetimibe.

\begin{tabular}{|c|c|c|c|c|}
\hline Parameter & Condition & Mean peak area \pm SD ( $\%$ RSD) & $\%$ Assay & Theoretical plates \\
\hline \multicolumn{5}{|c|}{ Rosuvastatin } \\
\hline \multirow{3}{*}{ Flow rate $(\mathrm{ml} / \mathrm{min})$} & 0.9 & \multirow{3}{*}{$3557208.67 \pm 8898.09(0.25)$} & \multirow{3}{*}{99.85} & \\
\hline & 1.0 & & & 8134 \\
\hline & 1.1 & & & \\
\hline \multirow{3}{*}{ Detection wavelength $(\mathrm{nm})$} & 252 & \multirow{3}{*}{$3551673.00 \pm 16076(0.45)$} & \multirow{3}{*}{99.69} & \\
\hline & 254 & & & 8530 \\
\hline & 256 & & & \\
\hline \multirow{3}{*}{ Mobile phase composition (v/v) } & $34: 66$ & \multirow{3}{*}{$3532385.67 \pm 26472.49(0.75)$} & \multirow{3}{*}{99.15} & \\
\hline & $32: 68$ & & & 8457 \\
\hline & $30: 70$ & & & \\
\hline \multirow{3}{*}{$\mathrm{pH}$} & 3.3 & \multirow{3}{*}{$3551673.67 \pm 38794$ (1.09) } & \multirow{3}{*}{99.69} & \\
\hline & 3.4 & & & 8265 \\
\hline & 3.5 & & & \\
\hline \multicolumn{5}{|c|}{ Ezetimibe } \\
\hline \multirow{3}{*}{ Flow rate $(\mathrm{ml} / \mathrm{min})$} & 0.9 & \multirow{3}{*}{$4346140.00 \pm 8730.76(0.20)$} & \multirow{3}{*}{99.78} & \\
\hline & 1.0 & & & 10986 \\
\hline & 1.1 & & & \\
\hline \multirow{3}{*}{ Detection wavelength (nm) } & 252 & \multirow{3}{*}{$4359196.67 \pm 11949.63(0.27)$} & \multirow{3}{*}{100.08} & \\
\hline & 254 & & & 10859 \\
\hline & 256 & & & \\
\hline \multirow{3}{*}{ Mobile phase composition (v/v) } & $34: 66$ & \multirow{3}{*}{$4318080.67 \pm 36416.96(0.84)$} & \multirow{3}{*}{99.13} & \\
\hline & $32: 68$ & & & 10945 \\
\hline & $30: 70$ & & & \\
\hline \multirow{3}{*}{$\mathrm{pH}$} & 3.3 & \multirow{3}{*}{$\begin{array}{c}4325117.33 \pm 30964.03 \\
(0.72)\end{array}$} & \multirow{3}{*}{99.30} & \\
\hline & 3.4 & & & 10674 \\
\hline & 3.5 & & & \\
\hline
\end{tabular}

Table 5: Robustness Studies of Rosuvastatin and Ezetimibe.

theoretical plates were found to be more than 2000 and the tailing factor was less than $<1.5-2$ or $<2$ indicating that the method is more selective and specific.

The specificity of the developed method can be determined from the stress studies and the percentage drug recovery was calculated from the peak area of the resultant chromatograms. During the stress studies it was observed that ezetimibe is highly sensitive towards alkaline degradation. The phenolic hydroxyl group present in its structure may be responsible for the major degradation during alkaline stress conditions.

\section{Conclusion}

The proposed method for the simultaneous determination of Rosuvastatin and Ezetimibe validated as per the ICH guidelines and it is simple, specific and robust and can be applied for the long term stability studies as well as for the kinetic studies of the pharmaceutical formulations.

\section{Acknowledgements}

The authors are grateful to University Grants Commission, New Delhi for their financial support and to M/s GITAM University, Visakhapatnam for providing the research facilities.

The authors have no conflict of interest. 
Citation: Mukthinuthalapati MA, Bukkapatnam V, Bandaru SPK, Grandhi NS (2014) Simultaneous Determination of Rosuvastatin and Ezetimibe in pharmaceutical formulations by Stability Indicating Liquid Chromatographic Method. J Bioequiv Availab 6: 174-180. doi:10.4172/jbb.1000200

\begin{tabular}{|c|c|c|c|c|c|c|}
\hline \multicolumn{4}{|c|}{ Solution stability } & \multicolumn{3}{|c|}{ Mobile phase stability } \\
\hline \multirow{2}{*}{ Time (hours) } & \multicolumn{2}{|c|}{ *Assay (\%) } & \multirow{2}{*}{ Mean \pm SD (\% RSD) } & \multicolumn{2}{|c|}{ Retention time (min) } & \multirow{2}{*}{ Mean \pm SD (\% RSD) } \\
\hline & RST & EZT & & RST & EZT & \\
\hline Initial & 98.71 & 96.19 & \multirow{3}{*}{ Rosuvastatin $98.70 \pm 0.0147(0.0149)$} & 3.542 & 4.628 & \multirow{3}{*}{ Rosuvastatin $3.542 \pm 0.0031(0.0875)$} \\
\hline 6 & 98.72 & 96.17 & & 3.540 & 4.624 & \\
\hline 12 & 98.69 & 96.20 & & 3.543 & 4.625 & \\
\hline 18 & 98.70 & 96.18 & \multirow{3}{*}{ Ezetimibe $96.19 \pm 0.0147(0.0153)$} & 3.538 & 4.618 & \multirow{3}{*}{$\begin{array}{c}\text { Ezetimibe } \\
4.624 \pm 0.0039(0.0843)\end{array}$} \\
\hline 24 & 98.71 & 96.18 & & 3.541 & 4.627 & \\
\hline 48 & 98.68 & 96.21 & & 3.547 & 4.620 & \\
\hline
\end{tabular}

*Mean of three replicates

Table 6: Analysis of Solution Stability and Mobile Phase Stability of Rosuvastatin and Ezetimibe.

\begin{tabular}{|c|c|c|c|c|c|c|}
\hline \multirow{2}{*}{ Formulation } & \multicolumn{2}{|c|}{ Labelled claim (mg) } & \multicolumn{2}{|c|}{ Amount found* (mg) } & \multicolumn{2}{|c|}{ Recovery* (\%) } \\
\hline & RST & EZT & RST & EZT & RST & EZT \\
\hline RAZEL-EZ ${ }^{\circledR}$ & 10 & 10 & 9.871 & 9.619 & 98.71 & 96.19 \\
\hline ROSUVAS-EZ ${ }^{\circledR}$ & 10 & 10 & 9.857 & 9.602 & 98.57 & 96.02 \\
\hline
\end{tabular}

* Mean of three replicates

Table 7: Analysis of Rosuvastatin and Ezetimibe in commercial formulation (Tablets).

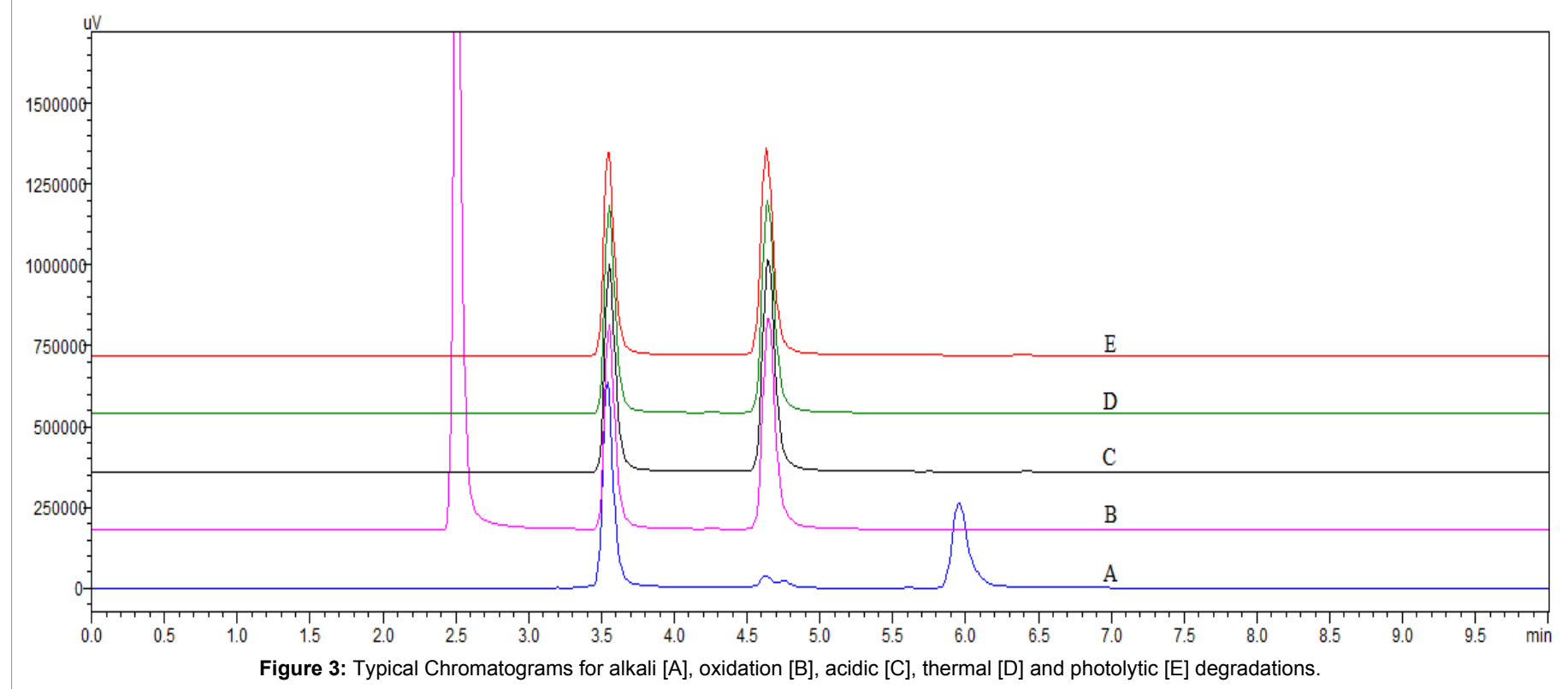

\begin{tabular}{|c|c|c|c|c|}
\hline Stress conditions & $\%$ Drug recovered & $\%$ Drug decomposed & Theoretical plates & Tailing factor \\
\hline \multicolumn{5}{|c|}{ Rosuvastatin } \\
\hline Standard drug & 100 & 0 & 8052.207 & 1.407 \\
\hline Acidic degradation & 93.61 & 6.39 & 8410.217 & 1.429 \\
\hline Alkaline degradation & 98.40 & 1.60 & 8352.050 & 1.436 \\
\hline Oxidative degradation & 94.34 & 5.66 & 8480.252 & 1.430 \\
\hline Thermal degradation & 92.74 & 7.26 & 8087.685 & 1.406 \\
\hline Photolytic degradation & 91.85 & 8.15 & 8456.438 & 1.428 \\
\hline \multicolumn{5}{|c|}{ Ezetimibe } \\
\hline Standard drug & 100 & 0 & 10793.731 & 1.392 \\
\hline Acidic degradation & 97.39 & 2.61 & 10966.786 & 1.413 \\
\hline Alkaline degradation & 5.27 & 94.73 & 9279.186 & 1.476 \\
\hline Oxidative degradation & 99.42 & 0.58 & 10824.863 & 1.469 \\
\hline Thermal degradation & 96.77 & 3.23 & 10667.446 & 1.390 \\
\hline Photolytic degradation & 93.70 & 6.30 & 10777.534 & 1.380 \\
\hline
\end{tabular}

Table 8: Forced degradation studies of Rosuvastatin and Ezetimibe. 
Citation: Mukthinuthalapati MA, Bukkapatnam V, Bandaru SPK, Grandhi NS (2014) Simultaneous Determination of Rosuvastatin and Ezetimibe in pharmaceutical formulations by Stability Indicating Liquid Chromatographic Method. J Bioequiv Availab 6: 174-180. doi:10.4172/jbb.1000200

\section{References}

1. O'Neil MJ (2006) The Merck Index, Merck Research Laboratories. (14th Edn) Merck and Co. Inc. Whitehouse Station, New Jersey.

2. Kosoglou T, Statkevich P, Johnson-Levonas AO, Paolini JF, Bergman AJ, et al. (2005) Ezetimibe: a review of its metabolism, pharmacokinetics and drug interactions. Clin Pharmacokinet 44: 467-494.

3. Van Heek M, France CF, Compton DS, McLeod RL, Yumibe NP, et al. (1997) In vivo metabolism-based discovery of a potent cholesterol absorption inhibitor, $\mathrm{SCH} 58235$, in the rat and rhesus monkey through the identification of the active metabolites of SCH48461. J Pharmacol Exp Ther 283: 157-163.

4. Knopp RH, Bays H, Manion CV, Lipka LJ, Melani L, et al. (2001) Effect of ezetimibe on serum concentrations of lipid soluble vitamins. Atherosclerosis 2: 90 .

5. McTaggart F, Buckett L, Davidson R, Holdgate G, McCormick A, et al. (2001) Preclinical and clinical pharmacology of Rosuvastatin, a new 3-hydroxy-3methylglutaryl coenzyme A reductase inhibitor. Am J Cardiol 87: 28B-32B.

6. Smita S, Sharma MC, Kohli DV, Chaturvedi SC (2010) Micellar liquid chromatographic method development for determination of rosuvastatin calcium and ezetimibe in pharmaceutical combination dosage form. Der Pharma Chemica 2: 371-377.

7. Mohammed IB, Prakash KV, Mohan KG (2013) RP-HPLC method for the simultaneous estimation of rosuvastatin and ezetimibe from their combination tablet dosage form. International Journal of Chemical and Analysis Science 4 205-209.

8. Sree Janardhanan V, Manavalan R, Valliappan K (2012) Chemometric technique for the optimization of chromatographic system: Simultaneous HPLC determination of rosuvastatin, telmisartan, ezetimibe and atorvastatin used in combined cardiovascular therapy. Arabian Journal Chemistry.

9. Varma Ch, Lakshmana Rao A, Dinda SC (2012) Development and validation of stability indicating RP-HPLC method for simultaneous estimation of rosuvastatin and ezetimibe in combined tablet dosage form. Rasayan Journal of Chemistry 5: 269-279.

10. Anuradha KG, Vishal DS (2010) Development and validation of a stabilityindicating reversed-phase HPLC method for simultaneous estimation of rosuvastatin and ezetimibe from their combination dosage forms. Eurasian Journal of Analysis Chemistry 5: 265-283.

11. Eswarudu MM, Mounica P, Venkatesh D, Nagalakshmi B (2012) Method development and validation for simultaneous estimation of rosuvastatin calcium and ezetimibe in pharmaceutical dosage form by RP-HPLC. International Research Journal of Pharmaceutical and Applied Sciences 2: 24-36.
12. Joshi H, Kumar S, Yadav YC, Seth AK (2012) New analytical method development and validation of rosuvastatin and ezetimibe in tablet dosage form. International Journal of Drug Discovery and Medicinal Research.

13. Smita S, Sharma MC, Kohli DV, Chaturvedi SC (2010) Simultaneous estimation of rosuvastatin calcium and ezetimibe in tablet dosage form by reverse phase high performance liquid chromatography. Optoelectronics and Advanced Materials: Rapid Communications 4: 238-241.

14. Varghese SJ, Ravi TK (2010) Determination of rosuvastatin and ezetimibe in a combined tablet dosage form using high-performance column liquid chromatography and high-performance thin-layer chromatography. J AOAC Int 93: $1222-1227$.

15. Sharma MC, Sharma S, Kohli DV, Sharma AD (2010) A validated HPTLC method for determination of simultaneous estimation rosuvastatin calcium and ezetimibe in pharmaceutical solid dosage form. Archives of Applied Science Research 2: 1-7.

16. Hiral JP, Bhanubhai NS (2013) Method development and validation of LC and densitometric-TLC for simultaneous estimation of rosuvastatin calcium and ezetimibe in combined dosage forms. Der Pharma Chemica 5: 208-215.

17. Anuradha KG, Vishal DS (2010) Simultaneous UV-spectrophotometric estimation of rosuvastatin and ezetimibe in their combined dosage forms. International Journal of Pharmacy and Pharmaceutical Sciences 1: 131-138.

18. Pandya CB, Channabasavaraj KP, Shridhara HS (2010) Simultaneous estimation of rosuvastatin calcium and ezetimibe in bulk and tablet dosage form by simultaneous equation method. International Journal of Chem Tech Research 2: 2140-2144.

19. Anuradha KG, Vishal DS (2010) Simultaneous estimation of rosuvastatin and ezetimibe by ratio spectra derivative spectrophotometry method in their fixed dosage forms. International Journal PharmTech 2: 404-410.

20. Ramzia IE, Ehab FE, Ahmed MK (2012) Spectrofluorometric determination of certain anti-hyperlipidemic agents in bulk and pharmaceutical preparations. Spectroscopy: An International Journal 27: 83-92.

21. Alvarenga L, Ferreira D, Altekruse D, Menezes JC, Lochmann D (2008) Table identification using near-infrared spectroscopy (NIRS) for pharmaceutical quality control. J Pharm Biomed Anal 48: 62-69.

22. Food and Drug Administration, HHS (2003) International Conference on Harmonisation; Stability Data Package for Registration Applications in Climatic Zones III and IV; Stability Testing of New Drug Substances and Products; availability. Notice. Fed Regist 68: 65717-65718. 